\title{
The Effect of Intensive Dietary Therapy on Serum High Density Lipoprotein Cholesterol in Patients with Type 2 (Non-Insulin-Dependent) Diabetes Mellitus: A Prospective Study
}

\author{
L. Kennedy ${ }^{1}$, K. Walshe ${ }^{1}$, D. R.Hadden ${ }^{1}$, J.A. Weaver ${ }^{1}$ and K. D. Buchanan ${ }^{2}$ \\ ${ }^{1}$ Diabetes Clinic, Royal Victoria Hospital, and ${ }^{2}$ Queen's University of Belfast, Belfast, Northern Ireland, UK
}

\begin{abstract}
Summary. Intensive dietary therapy in 57 newly diagnosed Type 2 (non-insulin-dependent) diabetic patients led to an increase, compared with pre-treatment levels, in serum high density lipoprotein (HDL) cholesterol and the HDL/total cholesterol ratio after 3 and 6 months $(0.05<p<0.1)$. The increase in HDL cholesterol was related to the degree of weight loss achieved. In 28 patients whose weight decreased by $\geqslant 10 \%$ average body weight during the 6 months, HDL cholesterol rose from $1.22 \pm 0.06$ to $1.36 \pm 0.06 \mathrm{mmol} / 1$ $(p<0.001)$, whereas patients who lost less weight showed no significant increase in HDL cholesterol. The increase in mean serum HDL-cholesterol levels in female patients was associat-
\end{abstract}

ed with a mean weight reduction of $12.1 \%$ average body weight. Patients who were obese at diagnosis lost more weight during the study than non-obese patients (mean 13.2 versus $5.6 \%$ average body weight), and showed a significant increase in serum HDL-cholesterol levels. We conclude that intensive dietary therapy may lead to a less atherogenic lipid profile in Type 2 diabetes, particularly in patients who achieve a major weight reduction.

Key words: HDL-cholesterol, triglyceride, glucose tolerance, dietary therapy, weight loss, Type 2 diabetes.
HDL cholesterol levels are inversely related to the risk of coronary heart disease, and it has been suggested that a low HDL cholesterol or HDL/total cholesterol ratio are major lipid risk factors [1, 2]. Several studies have demonstrated that HDL cholesterol levels are reduced in patients with Type 2 diabetes, a condition associated with an increased incidence of atherosclerosis [3-5]. It is not clear, however, whether treatment by diet or oral hypoglycaemic drugs influences HDL cholesterol levels.

As part of a prolonged prospective study of intensive dietary therapy in Type 2 diabetes [6], we have measured HDL cholesterol and other lipids in 57 newly diagnosed patients before and during 6 months dieting.

\section{Patients and Methods}

Fifty-seven newly diagnosed Type 2 diabetic patients were studied. All had symptoms attributable to hyperglycaemia or glycosuria at diagnosis. Their ages ranged from 43 to 69 years (mean 57 years) and there were 28 males and 29 females. Thirty-four patients were obese ( $>110 \%$ average body weight) and 23 non-obese $(<110 \%$ average body weight) at diagnosis. Twenty-one were known cigarette smokers and 34 were known alcohol consumers. Six patients were known to be taking thiazide diuretics, two to be taking $\beta$-adrenergic blocking agents and two more to be taking both these drugs at time of diagno- sis. To our knowledge, they continued on that therapy during the study period. At the time of diagnosis, a $50 \mathrm{~g}$ oral glucose tolerance test, with measurement of plasma insulin, was performed. Serum cholesterol, HDL cholesterol and triglyceride levels were measured after a 14-h overnight fast. The patients were then prescribed a diet in which $40 \%-45 \%$ of total energy was derived from carbohydrate with exclusion of foods rich in refined sugars. In the majority, the recommended energy value was $6300 \mathrm{~kJ} /$ day, but very obese patients received less (minimum $4200 \mathrm{~kJ}$ ) and those of normal or near normal body weight more (maximum $7600 \mathrm{~kJ}$ ). No specific recommendations were given as regards saturated and unsaturated fats. Full details of our diabetic diet therapy are published elsewhere [6]. At monthly intervals, patients were reviewed by a physician and a dietitian. Fasting glucose, insulin and lipid measurements were repeated at 3 and 6 months and the glucose tolerance test was repeated at 6 months.

Serum cholesterol and triglyceride levels were measured by standard Technicon sequential multiple analyzer and computer methods. Serum HDL cholesterol was measured, after precipitation of low density and very low density lipoproteins by manganese chloride and heparin, by the cholesterol-oxidase-para-amino phenazone technique as described previously [3]. The coefficient of variation in our laboratory is $4 \%$ within and $5 \%$ between assays. Plasma insulin was measured by radioimmunoassay with a sensitivity of $0.47 \mathrm{mU} / \mathrm{l}$, and coefficient of variation of $5.9 \%$ within and $19.6 \%$ between assays. Body weight was recorded as percentage average body weight for height and age derived from the tables of the Society of Actuaries [7].

Comparisons were made with the paired and unpaired Student's ttests, except for HDL/total cholesterol ratio for which the Wilcoxon rank test was used. 
Table 1. Plasma glucose and insulin levels and body weight in $57 \mathrm{pa-}$ tients with Type 2 diabetes treated with diet

\begin{tabular}{lccr}
\hline & $\begin{array}{l}\text { Before } \\
\text { treatment }\end{array}$ & 3 months & 6 months \\
\hline $\begin{array}{l}\text { Fasting plasma glucose } \\
\text { (mmol/1) }\end{array}$ & $13.3 \pm 0.5$ & $9.0 \pm 0.4^{\mathrm{b}}$ & $8.5 \pm 0.4^{\mathrm{b}}$ \\
$\begin{array}{l}\text { Peak plasma glucose } \\
\text { during OGTT (mmol/1) }\end{array}$ & $24.5 \pm 0.9$ & - & $16.3 \pm 0.6^{\mathrm{b}}$ \\
$\begin{array}{l}\text { Fasting plasma insulin } \\
\text { (mU/1) }\end{array}$ & $11.9 \pm 0.8$ & $10.6 \pm 0.8$ & $9.7 \pm 0.9$ \\
$\begin{array}{l}\text { Peak plasma insulin } \\
\text { during OGTT (mU/1) }\end{array}$ & $39.8 \pm 3.4$ & - & $49.1 \pm 5.9^{\mathrm{c}}$ \\
$\begin{array}{l}\text { Percentage mean } \\
\text { body weight }\end{array}$ & $120.7 \pm 2.6$ & $112.4 \pm 2.2^{\mathrm{b}}$ & $110.7 \pm 2.2^{\mathrm{b}}$ \\
\hline
\end{tabular}

Results expressed as mean \pm SEM. OGTT $=$ oral glucose tolerance test

${ }^{\mathrm{a}}$ In 54 patients only. ${ }^{\mathrm{b}} p<0.01$ compared with initial level, ${ }^{\mathrm{c}} 0.05<p$ $<0.1$ compared with initial level

Table 2. Serum cholesterol, HDL cholesterol, HDL/total cholesterol and triglyceride levels in 57 patients with Type 2 diabetes treated with diet

\begin{tabular}{|c|c|c|c|}
\hline & $\begin{array}{l}\text { Before } \\
\text { treatment }\end{array}$ & 3 months & 6 months \\
\hline Chol & 5 & 02 & 6.06 \\
\hline $\begin{array}{l}\text { HDL cholesterol } \\
(\mathrm{mmol} / \mathrm{l})\end{array}$ & $1.26 \pm 0.04$ & $1.34 \pm 0.05^{\mathrm{a}}$ & $1.34 \pm 0.04^{b}$ \\
\hline $\begin{array}{l}\text { HDL/total } \\
\text { cholesterol ratio }\end{array}$ & $0.210 \pm 0.007$ & $0.226 \pm 0.008^{a}$ & $0.225 \pm 0.009^{a}$ \\
\hline Triglyceride $(\mathrm{mmol} / \mathrm{l})$ & $1.91 \pm 0.09$ & $1.56 \pm 0.08^{b}$ & $1.58 \pm 0.08^{\mathrm{b}}$ \\
\hline
\end{tabular}

Results expressed as mean \pm SEM

a $0.05<p<0.10$ compared with initial level, ${ }^{\mathrm{b}} p<0.01$ compared with initial level

Table 3. Comparison of patients who were obese $(<110 \%$ average body weight) with patients who were non-obese $(\leqslant 110 \%$ average body weight) at diagnosis

\begin{tabular}{|c|c|c|c|c|}
\hline & Months & $\begin{array}{l}\text { Obese } \\
\text { subjects } \\
(n=34)\end{array}$ & $\begin{array}{l}\text { Non-obese } \\
\text { subjects } \\
(n=23)\end{array}$ & $\mathrm{p}$ \\
\hline $\begin{array}{l}\text { Percentage mean } \\
\text { body weight }\end{array}$ & $\begin{array}{l}0 \\
6\end{array}$ & $\begin{aligned} 132.1 & \pm 2.9 \\
118.9 & \pm 2.6 \\
p & <0.001\end{aligned}$ & $\begin{aligned} 103.1 & \pm 1.1 \\
97.5 & \pm 1.3 \\
p & <0.001\end{aligned}$ & $\begin{array}{l}- \\
-\end{array}$ \\
\hline $\begin{array}{l}\text { Fasting plasma } \\
\text { glucose }(\mathrm{mmol} / \mathrm{l})\end{array}$ & $\begin{array}{l}0 \\
6\end{array}$ & $\begin{aligned} 13.5 & \pm 0.62 \\
7.8 & \pm 0.39 \\
p & <0.001\end{aligned}$ & $\begin{array}{c}13.0 \pm 0.83 \\
9.5 \pm 0.75 \\
p<0.001\end{array}$ & $\begin{array}{l}\text { NS } \\
<0.025\end{array}$ \\
\hline $\begin{array}{l}\text { Peak plasma } \\
\text { glucose (mmol/1) }\end{array}$ & $\begin{array}{l}0 \\
6\end{array}$ & $\begin{aligned} 25.1 & \pm 1.32 \\
15.2 & \pm 0.73 \\
p & <0.001\end{aligned}$ & $\begin{aligned} 23.5 & \pm 1.30 \\
18.3 & \pm 1.11 \\
p & <0.001\end{aligned}$ & $\begin{array}{l}\text { NS } \\
<0.01\end{array}$ \\
\hline $\begin{array}{l}\text { Serum HDL } \\
\text { cholesterol }(\mathrm{mmol} / \mathrm{l})\end{array}$ & $\begin{array}{l}0 \\
6\end{array}$ & $\begin{array}{r}1.29 \pm 0.05 \\
1.38 \pm 0.06 \\
p<0.05\end{array}$ & $\begin{array}{c}1.22 \pm 0.06 \\
1.27 \pm 0.06 \\
\mathrm{NS}\end{array}$ & $\begin{array}{l}\text { NS } \\
\text { NS }\end{array}$ \\
\hline $\begin{array}{l}\text { HDL/total } \\
\text { cholesterol ratio }\end{array}$ & $\begin{array}{l}0 \\
6\end{array}$ & $\begin{array}{c}0.219 \pm 0.009 \\
0.228 \pm 0.010 \\
\text { NS }\end{array}$ & $\begin{array}{c}0.198 \pm 0.011 \\
0.223 \pm 0.017 \\
\text { NS }\end{array}$ & $\begin{array}{l}\text { NS } \\
\text { NS }\end{array}$ \\
\hline $\begin{array}{l}\text { Serum triglyceride } \\
(\mathrm{mmol} / \mathrm{l})\end{array}$ & $\begin{array}{l}0 \\
6\end{array}$ & $\begin{aligned} 1.89 & \pm 0.12 \\
1.57 & \pm 0.08 \\
p & <0.005\end{aligned}$ & $\begin{array}{c}1.94 \pm 0.13 \\
1.59 \pm 0.15 \\
p<0.025\end{array}$ & $\begin{array}{l}\text { NS } \\
\text { NS }\end{array}$ \\
\hline
\end{tabular}

Results expressed as mean $\pm \mathrm{SEM}$. NS $=$ not significant
Table 4. Effect of weight loss over 6 months on glucose tolerance and serum lipids in 57 Type 2 diabetic patients

\begin{tabular}{|c|c|c|c|c|}
\hline & Months & $\begin{array}{l}\text { Weight loss } \\
>10 \% \text { average } \\
\text { body } \\
\text { weight } \\
(n=28)\end{array}$ & $\begin{array}{l}\text { Weight loss } \\
<10 \% \text { average } \\
\text { body weight } \\
(n=29)\end{array}$ & $\mathrm{p}$ \\
\hline $\begin{array}{l}\text { Percentage average } \\
\text { body weight }\end{array}$ & $\begin{array}{l}0 \\
6\end{array}$ & $\begin{aligned} 130.7 & \pm 3.8 \\
114.4 & \pm 3.5 \\
p & <0.001\end{aligned}$ & $\begin{aligned} 110.4 & \pm 2.5 \\
106.5 & \pm 2.5 \\
p & <0.001\end{aligned}$ & $\begin{array}{l}<0.001 \\
<0.05\end{array}$ \\
\hline $\begin{array}{l}\text { Fasting plasma } \\
\text { glucose (mmol/l) }\end{array}$ & $\begin{array}{l}0 \\
6\end{array}$ & $\begin{array}{c}13.2 \pm 0.74 \\
7.6 \pm 0.42 \\
p<0.001\end{array}$ & $\begin{array}{c}13.3 \pm 0.67 \\
9.4 \pm 0.63 \\
p<0.001\end{array}$ & $\begin{array}{l}\text { NS } \\
<0.0025\end{array}$ \\
\hline $\begin{array}{l}\text { Peak plasma glucose } \\
(\mathrm{mmol} / 1)\end{array}$ & $\begin{array}{l}0 \\
6\end{array}$ & $\begin{aligned} 24.9 & \pm 1.59 \\
14.5 & \pm 0.84 \\
p & <0.001\end{aligned}$ & $\begin{array}{c}24.1 \pm 1.11 \\
18.2 \pm 0.88 \\
p<0.001\end{array}$ & $\begin{array}{l}\text { NS } \\
<0.005\end{array}$ \\
\hline $\begin{array}{l}\text { Serum HDL } \\
\text { cholesterol }(\mathrm{mmol} / \mathrm{l})\end{array}$ & l) $\begin{array}{l}0 \\
6\end{array}$ & $\begin{array}{r}1.22 \pm 0.06 \\
1.36 \pm 0.06 \\
p<0.001\end{array}$ & $\begin{array}{c}1.30 \pm 0.05 \\
1.32 \pm 0.07 \\
\text { NS }\end{array}$ & $\begin{array}{l}\text { NS } \\
\text { NS }\end{array}$ \\
\hline $\begin{array}{l}\mathrm{HDL} / \text { total } \\
\text { cholesterol ratio }\end{array}$ & $\begin{array}{l}0 \\
6\end{array}$ & $\begin{aligned} 0.216 & \pm 0.009 \\
0.237 & \pm 0.012 \\
p & <0.05\end{aligned}$ & $\begin{array}{c}0.206 \pm 0.011 \\
0.216 \pm 0.013 \\
\text { NS }\end{array}$ & $\begin{array}{l}\text { NS } \\
\text { NS }\end{array}$ \\
\hline $\begin{array}{l}\text { Serum triglyceride } \\
(\mathrm{mmol} / \mathrm{l})\end{array}$ & $\begin{array}{l}0 \\
6\end{array}$ & $\begin{array}{l}1.69 \pm 0.11 \\
1.36 \pm 0.08 \\
p<0.0025\end{array}$ & $\begin{aligned} 2.04 & \pm 0.14 \\
1.79 & \pm 0.11 \\
p & <0.025\end{aligned}$ & $\begin{array}{l}<0.01 \\
<0.0025\end{array}$ \\
\hline
\end{tabular}

Results expressed as mean \pm SEM. NS $=$ not significant

\section{Results}

Table 1 shows that in the 57 newly diagnosed patients, dietary therapy resulted in a significant reduction of fasting plasma glucose after 3 and 6 months, and peak plasma glucose during oral glucose tolerance test after 6 months, compared with pre-treatment values. Plasma insulin levels did not change, though there was a statistically insignificant increase in the peak insulin during the glucose tolerance test at 6 months compared with the time of diagnosis. Significant reductions in mean body weight were achieved at 3 and 6 months.

Lipid levels during the dietary study are shown for the patients as a whole in Table 2 . There was a reduction in serum triglyceride levels, whereas serum cholesterol did not change significantly. The increases in serum HDL cholesterol and HDL/total cholesterol ratio at 3 and 6 months compared with the time of diagnosis just failed to reach statistical significance at the 5\% level. When the data were examined cross-sectionally, serum HDL cholesterol was not significantly correlated with triglyceride levels, whereas the HDL/total cholesterol ratio had a significant negative correlation with triglyceride levels at all three study points $(r=-0.42$, -0.34 and -0.37 at zero, 3 and 6 months respectively). HDL cholesterol levels were similar in smokers and non-smokers, and in alcohol drinkers compared with abstainers.

In Tables 3, 4 and 5, patients have been subdivided according to body weight at diagnosis, weight loss over 6 months, and sex. There were no significant differences 
Table 5. Effect of 6 months diet on glucose tolerance and serum lipids in 28 male and 29 female Type 2 diabetic patients

\begin{tabular}{|c|c|c|c|c|}
\hline & Months & $\begin{array}{l}\text { Male } \\
\text { patients }\end{array}$ & $\begin{array}{l}\text { Female } \\
\text { patients }\end{array}$ & $p$ \\
\hline $\begin{array}{l}\text { Percentage average } \\
\text { body weight }\end{array}$ & $\begin{array}{l}0 \\
6\end{array}$ & $\begin{aligned} 113.3 & \pm 3.0 \\
105.5 & \pm 2.6 \\
p & <0.001\end{aligned}$ & $\begin{aligned} 127.2 & \pm 3.9 \\
115.1 & \pm 3.2 \\
p & <0.001\end{aligned}$ & $\begin{array}{l}<0.001 \\
<0.001\end{array}$ \\
\hline $\begin{array}{l}\text { Fasting plasma } \\
\text { glucose }(\mathrm{mmol} / \mathrm{l})\end{array}$ & $\begin{array}{l}0 \\
6\end{array}$ & $\begin{array}{c}13.0 \pm 0.78 \\
8.8 \pm 0.69 \\
p<0.001\end{array}$ & $\begin{array}{c}13.6 \pm 0.63 \\
8.3 \pm 0.41 \\
p<0.001\end{array}$ & $\begin{array}{l}\text { NS } \\
\text { NS }\end{array}$ \\
\hline $\begin{array}{l}\text { Peak plasma glucose } \\
(\mathrm{mmol} / \mathrm{l})\end{array}$ & $\begin{array}{ll}\text { e } & 0 \\
6\end{array}$ & $\begin{aligned} 23.4 & \pm 1.23 \\
16.2 & \pm 1.12 \\
p & <0.001\end{aligned}$ & $\begin{aligned} 25.6 & \pm 1.42 \\
16.5 & \pm 0.74 \\
p & <0.001\end{aligned}$ & $\begin{array}{l}\text { NS } \\
\text { NS }\end{array}$ \\
\hline $\begin{array}{l}\text { Serum HDL } \\
\text { cholesterol }(\mathrm{mmol} / \mathrm{l})\end{array}$ & $\begin{array}{l}0 \\
6\end{array}$ & $\begin{array}{c}1.24 \pm 0.05 \\
1.28 \pm 0.06 \\
\mathrm{NS}\end{array}$ & $\begin{aligned} 1.29 & \pm 0.06 \\
1.39 & \pm 0.07 \\
p & <0.005\end{aligned}$ & $\begin{array}{l}\text { NS } \\
\text { NS }\end{array}$ \\
\hline $\begin{array}{l}\mathrm{HDL} / \text { total } \\
\text { cholesterol ratio }\end{array}$ & $\begin{array}{l}0 \\
6\end{array}$ & $\begin{array}{c}0.210 \pm 0.010 \\
0.231 \pm 0.015 \\
\text { NS }\end{array}$ & $\begin{array}{c}0.212 \pm 0.009 \\
0.222 \pm 0.010 \\
\text { NS }\end{array}$ & $\begin{array}{l}\text { NS } \\
\text { NS }\end{array}$ \\
\hline $\begin{array}{l}\text { Serum triglyceride } \\
(\mathrm{mmol} / 1)\end{array}$ & $\begin{array}{l}0 \\
6\end{array}$ & $\begin{array}{l}1.82 \pm 0.11 \\
1.45 \pm 0.11 \\
p<0.0025\end{array}$ & $\begin{aligned} 1.99 & \pm 0.14 \\
1.70 & \pm 0.10 \\
p & <0.025\end{aligned}$ & $\begin{array}{l}\text { NS } \\
<0.05\end{array}$ \\
\hline
\end{tabular}

Results expressed as mean \pm SEM. NS $=$ not significant

or changes in these subgroups in serum cholesterol or plasma insulin, so these are not included. The 34 patients who were obese at diagnosis achieved a greater reduction in weight than the 23 non-obese patients, as might be expected (Table 3). Reduction in plasma glucose was also greater in the initially obese patients and at 6 months, the fasting and peak levels were significantly lower than in the non-obese group. Changes in triglyceride levels were similar in the two groups, but serum HDL cholesterol increased significantly only in the obese group.

Twenty-eight patients achieved a reduction in body weight of $\geqslant 10 \%$ average body weight. Compared with the 29 patients who had less weight loss, this group was significantly more obese initially and had significantly lower fasting and peak plasma glucose levels at 6 months (Table 4). Serum HDL cholesterol increased significantly in the group with $\geqslant 10 \%$ weight reduction. Serum triglyceride fell in both groups but was significantly lower, both at diagnosis and 6 months, in the patients with greater weight loss than those with less weight loss.

Female patients were significantly more obese, but lost more weight over 6 months than male patients (Table 5). Reduction in plasma glucose was similar in men and women but in these two groups, serum HDL cholesterol increased significantly only in the women. On the other hand, there was a greater reduction in serum triglyceride in the male patients.

\section{Discussion}

Much of the debate about why there is an increased incidence of atherosclerosis in diabetes mellitus concerns the role of lipid abnormalities. We have documented previously the triglyceride response to intensive dieting in Type 2 diabetes $[6,8]$ which we again observed in the present study. Low serum HDL cholesterol concentrations have been associated with the increased incidence of coronary heart disease in women with diabetes [9]. Reckless et al. [10] suggested that, although vascular disease in diabetes was related to low HDL cholesterol levels, a stronger correlation existed with high LDL cholesterol concentrations. In view of our previous finding of generally low concentrations of HDL cholesterol in Type 2 diabetes [3], it seemed pertinent therefore to investigate whether HDL cholesterol levels would be affected by therapy.

The present study demonstrates that intensive dietary therapy in Type 2 diabetes may result in increased levels of serum HDL cholesterol. It has been suggested that HDL cholesterol levels are decreased in Type 2 diabetes only if plasma triglyceride and/or glucose levels are elevated [11]. The results of our study do not support that view. In the group as a whole, mean plasma triglyceride fell as mean HDL cholesterol rose, but we found no correlation between the change in HDL cholesterol and the change in triglyceride. No correlation was found between plasma triglyceride and HDL cholesterol when analysed cross-sectionally at zero, 3 and 6 months, though there was a significant negative correlation between $\mathrm{HDL} /$ total cholesterol ratio and triglyceride levels on all three occasions. The increases in serum HDL cholesterol levels in the subgroups in Tables 3,4 and 5 were accompanied by decreases in serum triglyceride levels. However, those subgroups which did not show any increase in HDL cholesterol levels had similar, or even greater, decreases in triglyceride levels. Our data therefore support the recently expressed view of Taylor et al. [5] that Type 2 diabetes and hypertriglyceridaemia are independently associated with decreased HDL cholesterol levels.

The possibility that the level of glycaemia may be a factor in determining serum HDL cholesterol levels gets some support from the data in Tables 3 and 4 since glucose tolerance improved to a greater extent in those subgroups with increases in HDL cholesterol during the 6 months than those without. On the other hand, male and female patients had comparable improvements in glucose tolerance, but a significant increase in $\mathrm{HDL}$ cholesterol levels occurred only in the females (Table 5). Moreover, taking all 57 patients as a whole, there was no correlation between changes in HDL cholesterol and glucose levels.

Our study suggests that weight loss appears to be the major influence in elevating serum HDL cholesterol in the patients with Type 2 diabetes. When the results were analysed according to the amount of weight loss over the 6-month study period, HDL cholesterol increased significantly in patients with $\geqslant 10 \%$ average body weight loss. The mean weight loss over 6 months in female patients and patients who were obese at diagnosis was $12.1 \%$ and $13.2 \%$ average body weight respectively, again associated with significant increases in HDL 
cholesterol levels. These results accord with recent studies in non-diabetic obese subjects which suggested that a decrease in weight of $\geqslant 7 \%$ was required to produce a rise in HDL cholesterol [12].

Dietary content, and not just reduced caloric intake, may be an important contributory factor in our results. The major features of our recommended diet were reduced caloric intake, restriction of carbohydrate to $40 \%-45 \%$ of total energy and avoidance of refined sugars. The increased levels of HDL cholesterol which we observed mirror the results of Yudkin et al. [13] who found a lowering of HDL cholesterol in healthy nondiabetic volunteers consuming a diet rich in sucrose. These findings are particularly pertinent since there is at present considerable debate about the appropriate amount of carbohydrate to be included in the diabetic diet [14].

Some questions arise from our study which we are unable to answer at present. For example, would a greater reduction in weight in the non-obese patients result in a significant increase in HDL cholesterol levels, or is there a real difference in this respect between obese and non-obese Type 2 diabetic patients? Similarly, is our observed difference in response of HDL cholesterol in males and females simply due to the more efficient dieting of the females, or a true sex-based difference? Would treatment with insulin further increase HDL cholesterol levels by increasing the activity of lipoprotein lipase [15]? Would a diet of different composition, perhaps containing more polyunsaturated fats; give different results? Regardless of the answers to these questions, we believe that the present study again demonstrates the possible benefits of conscientious intensive dietary therapy in Type 2 diabetes, leading to a less atherogenic lipid profile, with elevation of HDL cholesterol levels, and that this should remain the primary treatment in the majority of patients.

Acknowledgements. We would like to thank Mr. T. Lavery for his technical assistance and Ms. M. Weller for her help with the manuscript.

\section{References}

1. Gordon T, Castelli WP, Hjortland MC, Kannel WB, Dawber TR (1977) High density lipoprotein as a protective factor against coronary heart disease. Am J Med 62: 707-714
2. Miller GJ, Miller NE (1975) Plasma high density lipoprotein concentration and development of ischaemic heart disease. Lancet 1 : 16-19

3. Kennedy AL, Lappin TRJ, Lavery TD, Hadden DR, Weaver JA, Montgomery DAD (1978) Relation of high density lipoprotein cholesterol concentration to type of diabetes and its control. Br Med J 2: 1191-1194

4. Nikkila EA (1978) Metabolic and endocrine control of plasma high density lipoprotein concentration. In: Gotto AM, Miller NE, Oliver MF (eds) High density lipoproteins, Elsevier-North Holland, Amsterdam, pp 177-192

5. Taylor KG, Wright AD, Carter TJN, Valente AJ, Betts SA, Matthews KA (1981), High density lipoprotein cholesterol and apolipoprotein A-1 levels at diagnosis in patients with non-insulin dependent diabetes. Diabetologia 20:535-539

6. Hadden DR, Wilson EA (1981) Dietary management of diabetes mellitus. Proc Nutr Soc 40: 247-255

7. Society of Actuaries, Build and Blood Pressure Study, vol I (1959) Society of Actuaries, Chicago, p 16

8. Hadden DR, Montgomery DAD, Skelly RJ,Trimble ER, Weaver JA, Wilson EA, Buchanan KD (1975) Maturity onset diabetes mellitus: response to intensive dietary management. Br Med J 2: 276-278

9. Gordon T, Castelli WP, Hjortland MC, Kannel WB, Dawber TR (1977) Diabetes, blood lipids and the role of obesity in coronary heart disease risk for women: the Framingham study. Ann Intern Med 87: 393-397

10. Reckless JPD, Betteridge DJ, Wu P, Payne B, Galton DJ (1978) High density and low density lipoproteins and prevalence of vascular disease in diabetes mellitus. Br Med $\mathbf{J} 1: 883-886$

11. Witzum J, Schonfeld G (1979) High density lipoproteins. Diabetes 28: $326-333$

12. Streja DA, Boyko E, Rabkin SW (1980) Changes in plasma high density lipoprotein cholesterol concentration after weight reduction in grossly obese subjects. Br Med J 2: 770-772

13. Yudkin J, Kang SS, Bruckdorfer KR (1980) Effects of high dietary sugar. Br Med J 2: 1396

14. Reaven GM (1980) How high the carbohydrate? Diabetologia 19: 409-413

15. Taylor KG, Galton DJ, Holdsworth G (1979) Insulin-dependent diabetes: a defect in the activity of lipoprotein lipase in adipose tissue. Diabetologia 16:313-317

Received: 7 September 1981

and in revised form: 12 February 1982

Laurence Kennedy MRCP

Sir George E Clark Metabolic Unit

Royal Victoria Hospital

Belfast BT12 6BA

Northern Ireland, UK 